\title{
Half-Caste Actresses in Colonial Brazilian Opera Houses
}

\section{Rosana Marreco Brescia}

Operatic and theatrical activity in the Portuguese kingdom, especially during the second half of the $18^{\text {th }}$ century, presents singular characteristics in comparison to other European countries, the presence of women on public stages being a notable example. In Portuguese America, construction of permanent opera houses effectively began from the 1760 s onwards ${ }^{1}$ and they performed a repertoire very similar to that performed in public theatres in Portugal - composed of adaptations/translations to Portuguese of foreign dramas and comedies, where musical numbers were interspersed with declaimed dialogues. However, the entire theatrical establishment was adapted to the local conditions and resources available in the colony. This included the employment of local artists, the majority of whom were half-caste. This practice remained unaltered until the arrival of the Portuguese court in 1808.

\section{1- Actresses in Portuguese Theatres in the Late $18^{\text {th }}$ Century}

Theatre historians in both Brazil and Portugal frequently mention that around the last quarter of the $18^{\text {th }}$ century, Queen Maria I forbade women to perform on public stages in Portugal. However, this prohibition has yet to be found in her Royal Orders (Brito 104). ${ }^{2}$ The Marquis of Pombal was forced to invite Venetian soprano Anna Zamperini to leave Lisbon in the middle of 1774 , since the cost of maintaining her expensive visit had led to the bankruptcy of the "Sociedade para a Subsistência dos Theatros Públicos da Corte" (founded in 1771) and there were rumors concerning her romantic affairs with several personalities in Lisbon's court, both civil and ecclesiastical. After the departure of Miss Zamperini, female roles started being performed by men in all major operatic performances given in Lisbon, causing some embarrassment to foreign travelers who were used to the theatrical practices of other European countries, where the presence of women on stages had been 
common for many years. Some of these travelers left us important reports about theatrical performances on both sides of the Atlantic.

Travelers' journals are extremely important to the study of LusoAmerican artistic practices, especially if one considers that they are rare historical sources that allow us to identify and understand the similarities and differences between the musical life in Portugal and Portuguese America and in the foreign travelers' home countries. The importance and value of this kind of literature cannot be underestimated due to the lack of reports available about theatrical or musical performances in general, or more specific information about the actors, costumes, repertoire, and the architecture of theatrical buildings. However, one must recognize that these travelers brought with them an entire spectrum of political, ethical, and socio-cultural baggage, which is evident in their reports. Rui Vieira Nery reminds us that the majority of travelers were military men, diplomats, traders, technicians, liberal professionals, and naturalists, and that there were very few travelers who belonged to the world of performing arts or culture in general. In most cases, these travelers had a basic knowledge about the arts, what was common to the "good society" of that period. Nevertheless, this assumed lack of knowledge of artistic subjects does not invalidate their commentaries or critiques of a form of art that originated in Europe. Instead, one can assume that their descriptions are fairly faithful to the practices that they have witnessed, always considering their opinions on aesthetics, racial issues, concepts of morality, and religious orders, as well as their lack of comprehension of cultural differences (Nery 72-91).

With regard to theatrical practices, and especially the practice of actors performing female roles in Portugal during the second half of the $18^{\text {th }}$ century, Englishman William Beckford left us an interesting description about the performance that he attended at the Rua dos Condes Theatre in 1787:

A shambling, blear-eyed boy, bundled out in weeds of the deepest sable, squeaked and bellowed alternately the part of a widowed princess. Another hob-e-di-hoy, tottering on high heeled shoes, represented her Egyptian Majesty, and warbled two airs with all the nauseous sweetness of a fluted falsetto. Though I could have boxed His ears for surfeiting mine so filthily, the audience were of a very different opinion, and were quite enthusiastic in their applause. (Beckford 404-05)

Another English traveler, James Cavanagh Murphy, described in 1789-1790 that: 
Of the late years no females were allowed to perform on the stage; hence the men were obliged to assume the female garb. How provoking it was to see the tender, the beautiful Ignez de Castro represented by one of these brawny, artificial wenches... instead of the delicate faltering accents of the fair victim he roared,

- like the ocean when the winds

fight with the waves. (Murphy 158)

Portuguese theatre historian António de Sousa Bastos described this prohibition as well, saying that, during the reign of Maria I, women were forbidden to perform in theatres, but fortunately the royal order was soon extinguished because it was "repugnant" to see roles of ingénues and elegant ladies performed by "big bearded boys" (11). According to Sousa Bastos, the Queen believed that it was scandalous to allow women on stage, and did not consider the fact that there are good and bad women in every class and it is not unusual to find libertine women in the aristocracy, as well as dignified and virtuous women in theatres.

\section{2- Half-Caste Actresses in Colonial Brazilian Opera Houses}

Despite what was happening in Lisbon, impresarios and owners of opera houses in Portuguese America seemed unaware of this prohibition, since I have found several references to actresses performing in many permanent theatres at the end of the $18^{\text {th }}$ century and in the early decades of the $19^{\text {th }}$ century, including the opera houses of São Paulo, Rio de Janeiro, Porto Alegre, and Vila Rica.

In the opera house of São Paulo, Auguste de Saint-Hilaire was able to watch a performance of L'Avare, probably an adaptation of Molière's work to the "Portuguese taste" that included some actresses. He writes:

They performed L'Avare and a small farce. The authors were artisans, the majority half-caste; the actresses, public women. The talent of these latter ones was in perfect harmony with their degree of morality; one could say that they were puppets moved by a thread. The majority of male actors weren't better as comedians; however, it was impossible not to recognize that some of them were born with a natural talent to the stage. (283-84)

The great majority of musicians employed in Portuguese America, both in sacred and profane performances, especially in the second half of the 18th century, consisted of half-caste men and women. African-American and European-American men were also employed, but in significantly smaller 
numbers. The colonial system itself was responsible for this phenomenon. White men were usually in charge of trade, administration, and economic activities; free and poor men and women were dedicated to mechanical work, artistic endeavors, and other areas not directly related to slave labor (Monteiro). With regard to the artists, Iracy del Nero writes that in 1804, musicians who were active in the captainship of Minas Gerais represented $41 \%$ of all liberal professionals who were engaged in the tertiary sector of the production system (Nero 279). Maurício Monteiro affirms that the majority of these half-caste men and women were never slaves. However, being a free halfcaste in a slavery-based society meant getting involved with other activities that did not relate to the immediate dynamics of the economy (Monteiro 7).

Based on the 1776 census, the captainship of Minas Gerais, for example, presented a greater number of half-caste and African men and women than white ones. It is not surprising then that traveler Richard Burton in the mid $19^{\text {th }}$ century described a city of five thousand inhabitants where only two families had pure European blood. The lack of white women in Portuguese America resulted in a large number of relationships between white men and African or half-caste women, even though marriage between persons of different color required a special license from the colonial administration; moreover, in the case of a mixed-race marriage, the man and his descendents were prohibited from ascending to a public position or becoming a member of one of the three Portuguese military orders-Christo, Aviz and Santiago (Boxer 70-71). According to Burton, "mulattism became a necessary evil" (qtd. in Freyre 76), an opinion that clearly indicates the negative light in which miscegenation was cast during the 18th and 19th centuries.

Although colonial society's main values were based on the criteria of birth, color, and honor, this did not prevent a non-white from accumulating a significant amount of money, and, sometimes, from rising in the society. Colonial women usually achieved this goal by concubinage with a white man; selling food; offering minor services, such as sewing, laundry, or delivery; prostitution; or working as actresses in permanent theatres, as I will discuss later (Furtado 43). Climbing the social ladder that separated common people from honored men and women was an important dream for many people who came from less privileged backgrounds, and this goal could be reached by the recognition of a special talent or competence acquired in a particular function (Cavalcanti 145). This is precisely the case of many half-caste musicians and comedians of both sexes throughout the Portuguese territory in America. 
In regards to Saint-Hilaire's comments about São Paulo's female comedians, the fact that the Frenchman affirms that they were "public women" could not be verified. However, this belief can be easily understood. Since the beginning of theatrical performances, the fact that a woman could express herself in public already was sufficient to confuse her with a prostitute and, in fact, some actresses exercised both professions. It is rather common to associate women who were related to the theatrical world with prostitution; this is even mentioned in treatises, such as the Scolasticae et morales disputations, by the Spaniard Pedro Hurtado de Mendoza in 1631, and Della Cristiana Moderazione del Teatro, by Italian Domenico Ottonelli in 1655 (Salvi 60). Being an actress has always offered women a certain amount of liberty, in addition to the possibility of a better life. Traveling, gifts, or even social acceptance were privileges usually denied to other lower class women (58). This possibility of growth and especially of social acceptance becomes even more justifiable if we consider the predicament of half-caste women living in the cities and villages of Portuguese America.

The fact is that, even if the French naturalist was right that the actresses of São Paulo's Opera House were also prostitutes, this was not always the case with actresses who performed in colonial theatres. The best example of the social acceptance and privileges that could be offered to a talented artist in the $18^{\text {th }}$ century is the case of soprano Joaquina Lapinha, prima donna of the Opera Nova in Rio de Janeiro.

\section{3- Joaquina Lapinha and the Operatic Scene in Portugal and Rio de Janeiro}

Daughter of the half-caste Maria da Lapa, Joaquina Maria da Conceição Lapa achieved a significant position in her time. She was the first, and probably only, native singer from Portuguese America who performed in a European theatre in the $18^{\text {th }}$ century. On May $16^{\text {th }}, 1791$, Lapinha requested a passport to travel to the capital of the kingdom, according to a document that I found during my research in the Arquivo Ultramarino of Lisbon (AHU, 159, D.11029). The Gazeta de Lisboa from January $16^{\text {th }}, 1795$ reports that: A 24 do corrente mez fará no Real Theatro de S. Carlos hum Concerto de Musica vocal e instrumental Joaquina Maria da Conceição Lapinha, natural do Brazil, onde se fizerão famosos os seus talentos músicos, que tem já sido admirados pelos melhores avaliadores desta capital. Os bilhetes e chaves dos camarotes e acharáõ em sua casa na rua dos Ourives da Prata na véspera, e na noite do indicado dia 
no mesmo Theatro. (Suplemento da Gazeta de Lisboa, Numero II, $16 / 01 / 1795)$

According to Ernesto Vieira in his Diccionário Biographico de Músicos Portugueses Lapinha had performed first in Oporto before arriving in Lisbon (15). However, Vieira does not mention the skin color of the singer from Rio de Janeiro, nor does the Gazeta de Lisboa. The only report that Lapinha was a half-caste comes from a Swedish man, Carl Israel Ruders, who attended one of her performances during his stay in Lisbon between 1798 and 1802.

Ruders writes that Lapinha was one of the first three singers to be hired by the Royal Theatre of São Carlos after the prohibition of Queen Maria I was lifted. In regards to the presence of women on the kingdom's stages, the Swedish traveler writes that the government acknowledged the justifiable criticism made during the Queen's reign that performances lost a great amount of their brightness due to the exclusion of women on stages, and three actresses obtained a license from His Royal Highness to perform in the Italian theatre (88). According to the Swede, the first actress, who was named Mariana Albani, did not impress him particularly. She was enthusiastically applauded more for the pleasure of the novelty than for her talent, which was rather mediocre both in singing and acting (92). The second artist, Luisa Gerbini, was a violinist who gave several performances in the same theatre before being hired as an actress. Ruders says that she was a good and confident singer, with a clear, strong, and pleasant voice, although she was a bit cold in acting (93). With regard to the third, Joaquina Lapinha, Ruders apparently was only slightly bothered by the color of her skin and not at all by her musical or acting skills. He says: "A terceira atriz se chama Joaquina Lapinha. Ela é natural do Brasil e é filha de uma mulata, por cujo motivo tem a pele bastante escura. Este inconveniente, porém, remedeia-se com cosméticos. Fora disso, tem uma figura imponente, boa voz e muito sentimento dramático" (93). Even for Ruders, the "inconventiente" of the "pele bastante escura" could be easily corrected, proof that Lapinha's talent and recognition in some of the major theatres of the Portuguese world were enough to grant her significant artistic acceptance, far from the reality of the great majority of the half-caste women in Portuguese America.

On August $6^{\text {th }}, 1805$, the soprano required another passport to return to Rio de Janeiro with her mother, Maria da Lapa, and two other free slaves, Ignacia and Eva, all natives from the same city (AHU, 235, D.15673). Back in Rio de Janeiro with the company directed by Manuel Luis Ferreira, Lapinha performed works by Marcos Portugal and other important composers. 
Some libretti containing the name of Joaquina are still preserved in some Portuguese archives. They include $A$ União Venturosa, a musical drama by Fortunato Maziotti, which was performed in the Royal Theatre of Rio de Janeiro on the birthday of the Prince Regent Dom João in 1811, and L'oro non compra amore, by Marcos Portugal, which was performed in the same theatre on December $17^{\text {th }}, 1811$ - the birthday of Queen Maria I. In some of the scores used by Lapinha, it is clear that the singer had a considerably generous voice with regards to the tessitura, besides several technical qualities such as great coloratura and the ability to sustain long phrases in legato. One of the roles probably sung by Joaquina in Rio de Janeiro, the main role of the opera Zaira, composed by Bernardo José de Souza Queiroz (Budasz 2008), ${ }^{3}$ requires all of the above mentioned characteristics.

Further evidence of the social and artistic prestige achieved by the singer from Rio de Janeiro was an invitation for her to perform in a concert alongside other foreign artists, such as the example mentioned in the Gazeta do Rio de Janeiro n. ${ }^{\circ} 13$ of 1809, and reproduced by Antônio Carlos dos Santos:

Senhora d'Anay, cantora e actriz, recém chegada de Londres, onde nos teatros, assim como nos de Paris ela sempre se apresentou, informa com muito respeito aos cidadãos desta corte, que ela tem a intenção de dar um concerto de música vocal, e instrumental, na casa de número 28, na Praia de Dom Manuel, no 14 do corrente. Neste concerto cantarão ela, e a Senhora Joaquina Lapinha, as mais belas músicas escolhidas dentre a obra dos melhores compositores, e tocarão os senhores Lansaldo e Lami concertos de violino, e a orquestra tocara as melhores aberturas de Mozart. Vendem-se bilhetes em sua casa, no número 8 , Rua de São José, e o preço é de $4 \$ 000$ reis. (Santos 342)

Joaquina Lapinha is the best example of a half-caste actress active in Portuguese America at the end of the $18^{\text {th }}$ century. She was able to achieve significant recognition in colonial society thanks to her talent and despite the color of her skin and her social background.

\section{4- Other Actresses in Colonial Brazilian Theatres}

In the Opera House of Vila Rica, capital of colonial Minas Gerais, names of female actresses have been mentioned since the very beginning of its operation. Its owner, Colonel João de Sousa Lisboa, actually mentioned them as early as September of 1770 , precisely three months after the opening of the theatre. In a letter to Dr. Joaquim José Freire de Andrade, Sousa Lisboa 
wrote: "Saberá vossa mercê que ja tenho na Caza da Opera duas fêmeas que reprezentão e hua delas com todo o primor muito melhor que as do Rio de Janeiro, e estimarei que vossa mercê tenha também por la divertimentos" (APM, CC - 1174, fls. $41 \mathrm{v}, 42$ ).

The names of several actresses engaged at the Opera House of Vila Rica in the last decades of the $18^{\text {th }}$ century and first decades of the $19^{\text {th }}$ century are mentioned in several documents from very different sources, ranging from lists of payments to the opera house's employees to lawsuits. In this article, we will mention a few actresses who apparently lived in very different social conditions.

An interesting case is that of the comedian Violanta Mônica da Cruz, who performed in Vila Rica in the 1780s. I have found in the Arquivo Histórico do Museu da Inconfidência in Ouro Preto a deed drawn up between her and the priest Manuel Machado Dutra that verifies that Dutra had borrowed two hundred thousand réis from Violanta to become a priest. In exchange, she could use two of his houses in Vila Rica without payment of rent of any kind. If, during that period of six years, the priest was unable to return the money, Violanta would become the owner of the two houses (AHMI, Livro de Notas, v.168, fls 98 and 98v). If this Violanta Mônica is, indeed, the actress of the opera house of Vila Rica, ${ }^{4}$ the deed is very important since two hundred thousand réis is a considerable amount of money for an actress to lend without being impaired financially. In the end, Violanta apparently died in poverty, according to the 1804 census. In this document, one learns that she was born around 1754 and had two children, Agostinha and Thereza, who were 30 and 25 years of age, respectively, in 1804 . She was also raising a four year old boy named Ivo Antônio, who was probably a grandson. At the time, the family lived in the neighborhood of Cabeças in Vila Rica, which indicates that she was not living in either of the houses mentioned in the deed as property of the priest Manuel Machado Dutra (Mathias 164).

The second actress, Francisca Luciana, is mentioned in a lawsuit against the impresario of the opera house, Mr. Antônio de Padua, who claimed that she owned him 137 octaves of gold on January $9^{\text {th }}, 1801$. This extremely high sum was lent by the impresario to the actress to enable her to pay her rent, buy fabric to make dresses, pay for boxes in the opera house, purchase tickets, and even for buying food. The situation of Francisca Luciana seems to have been one of extreme misery, according to the testimony of Antônio de Padua during the lawsuit. In one of his statements, he alleged that the actress had asked for two octaves of gold, claiming that she had nothing to eat 
(AHMI, $1^{\circ}$ Oficio, Códice 155, Auto 2081). Despite her financial difficulties and problems with one of the impresarios of the Vila Rica theatre, Francisca Luciana was still performing in the 1816 season, according to a list of employees of the opera house of that year (Minas Gerais 6), suggesting that her legal problems had not affected her career in this theatre.

This list of employees of the opera house of Vila Rica for the 1816 season indicates that the company employed 36 artists, consisting of 20 actors of both sexes and 16 orchestra musicians. Among the employees' names is that of the renowned composer João de Deus de Castro Lobo, who was responsible for directing the instrumental ensemble. The actresses were Francisca Luciana, Luiza Josefa, Anna Serrinha, and Felicidade Vaqueta. This list indicates that actresses represented $20 \%$ of the company, not including the orchestra musicians, and that they were better paid than male artists, receiving $1 \$ 800$ réis per performance while men received $1 \$ 600$ réis (Minas Gerais).

Another important document is the "Mapa dos actores empregados na Casa da Ópera de Vila Rica em 1820" (APM, CC 134, fl.5 e 5v), which is preserved in the Arquivo Público Mineiro in Belo Horizonte, Brazil. In this document, one can verify the names of several artists and employees of the theatre, including the prompter, the stage manager, a dancer, three actresses (Anna Clara do Nascimento, Anna Soares, and Thomasia de Sousa), the carpenter, the tailor, the hair dresser, the administrator of keys, the doorman of the parterre and of the left side boxes, the ticket officer and doorman of the right side boxes, the principal doorman, and other employees. This "Map" documents the performance of five operas, and includes the payments to each employee for each performance. Among the actors were several members of the family of the remarkable musician Castro Lobo. They included Gabriel de Castro Lobo, the best paid artist in the company with a salary of $1 \$ 600$ réis per performance, while other men in the company received a maximum of $1 \$ 200$ réis per performance. Actress Anna Clara do Nascimento had a higher salary than that of ordinary men in the company, reaching a total of $1 \$ 600$ réis per performance, the same compensation as the best paid male artist. Anna Soares apparently had a less important role than Anna Clara do Nascimento since she took part in only one of the five operas performed, although her salary was exactly the same as her colleague. Thomasia de Sousa received $\$ 600$ réis for each of the five performances. The following page of the "Map" includes the signatures of each of the employees. One can see that Anna Soares could not write and was represented by another person in the contract. However, the probable first lady of the company, Anna Clara 
do Nascimento, was sufficiently educated that she could sign her own name. The list does not include the signature of Thomasia de Sousa.

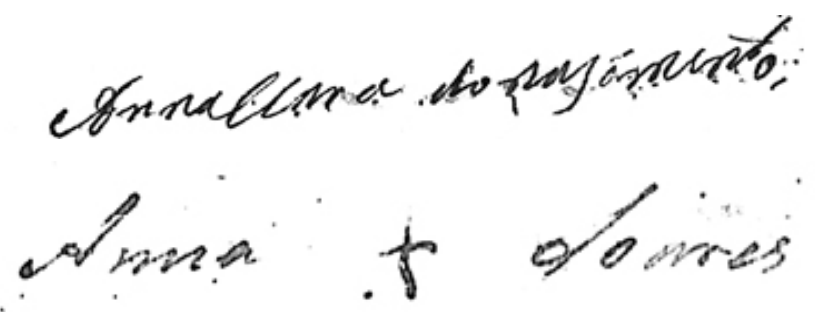

Fig. 1 -. Public Archives of Minas Gerais, CC.134, 21.140/4, fl.5v.

This brings us to the subject of education in Portuguese America. In most of the colony, religious institutions and private teachers were responsible for education in general, as well as for musical education. Most of these institutions, and sometimes private teachers as well, accepted only male students. This leads us to the hypothesis that the great majority of women were illiterate. However, according to research conducted by Nireu Cavalcanti on education in Rio de Janeiro in the $18^{\text {th }}$ century, $92 \%$ of men and $60 \%$ of women in a sample of 5,960 people could sign their names with a certain degree of confidence (Cavalcanti 157-58). This proves that informal education based on personal relationships cannot be ignored.

Female singers engaged by opera houses and the Municipal Chambers were obliged to obtain private instruction since they were forbidden to attend religious institutions for that purpose. One example is the festivities in Vila Rica to celebrate the marriage of Prince João and Princess Carlota in 1786, where at least three female singers (Ana Joaquina, Violanta Mônica, and Antonia Fontes) were engaged to perform the operas for the occasion. The payment receipts for this event confirm that Gabriel de Castro Lobo received three octaves of gold to teach the music to Violante Mônica, Julião Pereira was paid one octave of gold to teach one opera to Ana Joaquina, and another person was paid to teach the music to "the ladies" (Lange 49-56). The same method was used in Porto Alegre's opera house, where a signed contract between actress Maria Benedita de Queiroz Montenegro and impresario Pedro Pereira Bragança states that the actress was obliged to learn two new operas and two entremezes per month, in addition to always being ready to rehearse and to learn all sorts of songs chosen by the impresario for the enhancement of the opera. She should also follow the guidance of the teacher hired by the 
same impresario (Damasceno 4-5). This method indicates how female singers and comedians learned their parts in operas, but not how women who came from less privileged backgrouds could have access to instruction in reading and writing. The fact that some of the previously mentioned actresses, such as Ana Clara do Nascimento, Violanta Mônica da Cruz, and Maria Benedita de Queiroz Montenegro, were sufficiently educated to sign their names with confidence indicates that these women had received some kind of informal education.

\section{5- Actors Performing Female Roles in Colonial Brazilian Opera Houses}

Despite the presence of women in the public theatres of Portuguese America, the practice of having male actors dressed as women to perform female roles was not totally unknown. Austrian traveler Johann Emanuel Pohl, who saw a few performances between 1817 and 1821, provides the following information:

Como se julga impróprio que as senhoras representem um papel no teatro, todos os papéis femininos sao desempenhados por homens. Bem se pode imaginar a impressão que causa a um europeu tal modo de representar. Embora só haja espetaculo uma vez por semana, o teatro fecha-se quando o governador adoece. Durante minha estada em Vila Rica, tive ensejo de assistir a três representações e a uma opereta de Pittersdorf [Dittersdorf], bem como a "Mädchen von Marienburg", e "Inês de Castro", a peça predileta dos portugueses. Como a companhia então presente contava com duas mulheres, tive oportunidade de ver a prima-donna na ópera e a "Mädchen von Marienburg", sendo que se resolveu representar o último papel uma menina de treze anos. O melho êxito teve a representação da "Inês de Castro", que foi muito aplaudida, embora o papel principal, o de Inês, fosse desempenhado por um homem. (Pohl 417-18)

Even João de Sousa Lisboa, in a letter dated January $4^{\text {th }} 1771$, only seven months after the first performance in his opera house, tells his friend José Gomes Freire de Andrade in Vila Boa, Goiás that:

$\mathrm{vm}^{\text {ce }}$ há de vir agora na minha casa da opera entre duas raparigas de bom gosto, e estao representando com muita aceitaçaõ, que os que $\mathrm{vm}^{\mathrm{ce}}$ vio heraõ homens que jà ninguem os quer ver, se ellas naõ vaõ ao tablado, seguro the que vm. ${ }^{\text {ce }}$ logo tinha saúde e parece me que $\mathrm{vm}^{\text {ce }}$ so com essa noticia sara, naõ me aproveito das dessa terra por 
q..$^{\text {to }}$ como là estive, e as vy não sò saõ dezengano do Mundo, se naõ tambem de nos mesmos. (APM, CC.1174, fl.46v)

In this letter, the owner of the opera house of Vila Rica indicates that the practices of using actresses and disguised actors for the performance of female roles were employed simultaneously since the inauguration of that theatre. In fact, I believe that the task of finding actors and actresses who were willing to perform in the captainship of Minas Gerais was not a simple one, although they were considerably well paid. In another letter written to Dr. João Caetano Pinto, who lived in the Arraial do Tejuco, dated July $13^{\text {th }}$, 1770, Sousa Lisboa says:

Também terá chegado a noticia de vossa mercê que mandei fazer aqui hua Caza de Opera que se acha concluida mas o melhor lhe falta que são alguas figuras para reprezentar o grasiozo para o papel de [bobo] se o amigo ahy tiver noticia de algum sogeito que tenha exzercitado em operas e ainda que não tenha se tiver propriedade para reprezentar eu caresso dellas, vossa mercê lhe fale, e saber delles se querem vir e avizar-me da sua detreminação. (APM, CC.1205, fls. 27v and 28) One should mention that besides working for a permanent opera house, actors and actresses in Portuguese America could be engaged by the Municipal Chambers to perform in the ephemeral festivities related to the Portuguese Empire. However, since these performances happened very few times a year, they were certainly not enough to cover all expenses of a "professional" comedian. In other words, one could not live only from performing operas unless he or she was actually engaged by a permanent theatre. Therefore, although comedians were well paid, the profession's job opportunities were extremely limited.

In conclusion, if the ban imposed by Queen Maria I regarding women on public stages really did exist, it was never completely adopted by owners and impresarios of opera houses in Portuguese America. Standing out among the actresses who were active in colonial Brazilian theatres was the soprano from Rio de Janeiro Joaquina Maria da Conceição Lapinha. Other actresses developed significant careers in other parts of the colony. These actresses were very well paid for their services in opera houses, their salaries sometimes exceeding those of their male colleagues. Nevertheless, despite the presence of women on public stages from the beginning of the operation of permanent opera houses, it is certain that they performed concurrently with male actors performing female roles. I believe that this latter practice was unrelated to the supposed prohibition by Queen Maria I at the end of the $18^{\text {th }}$ 
century and also was not due to any religious or moral beliefs. More likely, it was an adaptation to the resources available in the villages and cities of Portuguese America to produce theatrical and operatic performances in the $18^{\text {th }}$ and $19^{\text {th }}$ centuries.

\section{Université Sorbonne Paris IV / CESEM - Universidade Nova de Lisboa}

\section{Notes}

1 I have found references to three permanent theatres built in Portuguese America before the 1760s: the Prezépio of Rio de Janeiro, built in 1719; the Municipal Chamber Theatre in Salvador, Bahia, in operation between 1729 and 1734; and the first opera house of Vila Rica, built before 1751.

2 Even if the prohibition really existed, it was certainly not completely observed. Around 1780, Cecilia Rosa de Aguiar was still performing in Lisbon, according to an article published in 1781 in the Journal de Littérature.

3 The opera Zaira was edited by Brazilian musicologist Rogério Budasz for a performance at the XX International Festival of Ancient Music in Juiz de Fora in July, 2004.

4 The deed does not mention the occupation of Violanta Mônica, but this is probably the same Violanta who performed in operas in Vila Rica around 1786 since the two have exactly the same name and the dates coincides with the actress' lifetime. Besides, the survey of 1804 does not mention any other Violanta Mônica da Cruz living in Vila Rica in that year.

\section{Works Cited}

\section{Archives}

Arquivo Histórico do Museu da Inconfidência - Ouro Preto, Brazil

Livro de Notas, $1^{\circ}$ Oficio, Codice 155, Auto 2081.

Livro de Notas, v.168, fls 98 y 98v.

Arquivo Público Mineiro - Belo Horizonte, Brazil

APM, Coleção da Casa dos Contos, CC - Cx. 134, 21.140/4, fl.5 y $5 \mathrm{v}$.

APM, Coleção da Casa dos Contos, CC.1174, fl.46v.

APM, Coleção da Casa dos Contos, CC - 1205, fls. 27v y 28.

Coleção da Casa dos Contos, CC - 1174, fls. 41 v, 42 y 42 v.

Arquivo Histórico Ultramarino - Lisbon, Portugal

AHU_ACL_CU_017, Cx.141, D.11029.

AHU_ACL_CU_017, Cx.235, D.15673.

Hemeroteca Mineira - Belo Horizonte, Brazil

Minas Gerais, Belo Horizonte, Órgão oficial dos Poderes do Estado, 19th

October 1898. 
Library of Ajuda - Lisbon, Portugal

Libretto - L'oro non compra amore. (BA), 151-VII-12, n4.

National Library of Portugal - Lisbon, Portugal

Gazeta de Lisboa, Numero II, (Suplemento) - 16/01/1795, F.P.192, microfilme N.36.

\section{Books and Articles}

Bastos, António de Sousa. Diccionario do Theatro Portuguez. Lisbon: Libanio da Silva, 1908.

Beckford, William. The History of the Caliph Vathek and European Travels. London: Ward, Lock and Co., 1891.

Boxer, Charles Ralph. O Império Colonial Português. Lisbon: Edições 70, 1969.

Brito, Manuel Carlos de. Opera in Portugal in the Eighteenth Century. Cambridge, UK: Cambridge UP, 1989.

Budasz, Rogério. Teatro e Música na América Portuguesa: opera e teatro musical no Brasil (1700-1822). Curitiba, Brazil: Deartes/Imprensa UniversitáriaUFPR, 2008.

Burton, Richard. The Highlands of the Brazil. London: Tinsley Brothers, 1869.

Cavalcanti, Nireu. O Rio de Janeiro Setecentista: a vida e a construção da cidade da invasão francesa até a chegada da corte. Rio de Janeiro: Jorge Zahar Editora, 2004.

Damasceno, Athos. Palco, Salão e Picadeiro em Porto Alegre no Século XIX. Rio de Janeiro: Editora Globo, 1956.

Freyre, Gilberto. Sobrados e mucambos: decadência do patriarcado rural e desenvolvimento do urbano. 2nd vol. Lisboa: Livros do Brasil, 1936.

Furtado, Junia Ferreira. Chica da Silva e o contratador dos diamantes: o outro lado do mito. São Paulo: Companhia das Letras, 2003.

Lange, Francisco Curt. "La música en Minas Gerais: un informe preliminar.” Boletin latino-americano de música 6 (1946): 409-94.

Mathias, Herculano Gomes. Um Recenseamento na Capitania de Minas Gerais, Vila Rica-1804. Rio de Janeiro: Ministério da Justiça, Arquivo Nacional, 1969.

Monteiro, Maurício. "Música e Mestiçagem no Brasil." Nuevo Mundo Mundos Nuevos (2006). April 12, 2010. < http://nuevomundo.revues.org/index1626. html>. Web.

Murphy, James Cavanagh. Travels in Portugal; Through the Provinces of Entre Douro e Minho, Beira, Estremadura, and Allem-Tejo, in the Years 1789 and 1790. Consisting observations on the manners, customs, trade, public buildings, arts, antiques \&c. of that Kingdom. Illustrated with plates. London: Strahan, 1795.

Nero, Iracy del. Vila Rica - População (1719-1826). São Paulo: Instituto de Pesquisas Econômicas da Faculdade de Economia e Administração da Universidade de São Paulo, 1979. 
Nery, Rui Vieira. "O Olhar Exterior: Os Relatos dos Viajantes Estrangeiros como Fontes para o Estudo da Vida Musical Luso-Brasileira nos Finais do Antigo Regime." Actas do colóquio A Música no Brasil Colonial, Lisboa 2000. Ed. Nery. Lisbon: Fundação Calouste Gulbenkian, 2000. 72-91.

Pohl, Johann Emanuel. Viagem ao Interior do Brasil. Trans. Milton Amado and Eugênio Amado. Belo Horizonte, Brazil: Editora Itatiaia y Editora da Universidade de São Paulo, 1976.

Ruders, Carl Israel. Viagem a Portugal 1798-1802. Trans. Antônio Feijó. Introduction and notes Castelo Branco Chaves. Série Portugal e os Estrangeiros. Lisbon: Biblioteca Nacional, 1981.

Saint-Hilaire, Auguste de. Voyage dans les provinces de Saint-Paul et de Sainte-Catherine. Paris: Arthus Bertrand, 1851.

Salvi, Marcella. Escenas en conflicto: El teatro español e italiano desde los márgenes del Barroco. New York: Peter Lang Publishing Inc., 2005.

Santos, Antônio Carlos dos. "O timbre feminino e negro da música antiga brasileira (sec.XIX)." Anais do V Encontro de Musicologia Histórica Juiz de Fora Julio de 2002. Ed. Paulo Castagna. Juiz de Fora, Brazil: Centro Cultural Pro-Música, 2004. 342.

Vieira, Ernesto. Diccionario Biographico de Musicos Portugueses: Historia e Bibliographia da Musica em Portugal. Lisbon: Typographia Mattos Moreira \& Pinheiro, 1900. 
